\title{
Perencanaan proses pengolahan sampah plastik dan kebun di Kabupaten Boyolali dengan prinsip karbonisasi menjadi energi
}

\section{Mayang Ananda Rini, Novica Ayu Sari, Whindy Ndaru Oktaviani, Rarastika Nur Ghaida, Mega Mutiara Sari, I Wayan Koko Suryawan*}

\author{
Program Studi Teknik Lingkungan, Fakultas Perencanaan Infrastruktur, Universitas Pertamina Simprug, Kec. Kby. \\ Lama, Kota Jakarta Selatan, Daerah Khusus Ibukota Jakarta 12220 \\ Naskah diterima 24/07/2021; direvisi 15/08/2021; disetujui 30/08/2021 \\ doi: https://doi.org/10.24843/JEM.2021.v14.i01.p06
}

\begin{abstract}
Abstrak
Pengelolaan sampah di Kabupaten Boyolali menjadi salah satu tantangan untuk mencapai kriteria smart city. Sampah di Kabupaten Bolali mengandung komposisi plastik sebesar 56,12\% dan sampah kebun sebesar $37.13 \%$. Sampah plastik dan kebun memiliki nilai kalor yang melebihi $5000 \mathrm{kkcal} / \mathrm{kg}$, sehingga berpotensi untuk untuk dijadikan briket. Tujuan studi ini adalah untuk menganalisa perencanaan yang tepat yand dapat dilakukan di Kabupaten Boyolali dengan menggunakan proses karbonisasi sehingga menghasilkan briket yang berkualitas. Proses pengolahan sampah terdiri dari proses pemilahan sampah plastik dan sampah kebun, kemudian dilakukan pencacahan, kemudian dilakukan karbonisasi, sehingga didapatkan briket yang sesuai standard. Total sampah yang diolah adalah sekitar 90 ton/hari dan 45 ton/hari, untuk sampah plastik dan sampah kebun masing-masing. Jika proses ini diterapkan setidaknya dapat mereduksi sebanyak $50,77 \%$ timbulan sampah di Kabupaten Boyolali. Total pemulihan energi sampah dari fasilitas karbonisasi dapat mencapai 5611384,6 MJ/hari. Kebutuhan lahan dari proses pengolahan mencapai $117 \mathrm{~m}^{2}$ dengan proses layouting memiliki dimensi $264 \mathrm{~m}$ x $65 \mathrm{~m}$.
\end{abstract}

Kata kunci: Sampah, energi, karbonisasi, briket, reduksi

\begin{abstract}
Waste management in Boyolali Regency is one of the challenges to achieve the smart city criteria. Garbage in Bolali Regency contains $56.12 \%$ plastic composition and $37.13 \%$ garden waste. Plastic and garden waste has a calorific value that exceeds $5000 \mathrm{kcal} / \mathrm{kg}$, so it can be used as briquettes. The purpose of this study is to analyze the proper planning and can be carried out in Boyolali Regency by using the carbonization process to produce quality briquettes. The waste processing process consists of the process of sorting plastic waste and garden waste, then counting, then carbonization is carried out, so that briquettes are obtained according to standards. The total waste treated is about 90 ton/day and 45 ton/day, for plastic waste and garden waste respectively. If this process is applied at least, it can reduce as much as $50.77 \%$ of waste generation in Boyolali Regency. The total recovery of waste energy from the carbonization facility can reach $5611384.6 \mathrm{MJ} /$ day. The land requirement from the processing process reaches $117^{2}$ with the layouting process having dimensions of $264 \mathrm{~m} \times 65 \mathrm{~m}$.
\end{abstract}

Keywords: Waste, energy, carbonization, briquettes, reduction

\section{Pendahuluan}

Kabupaten Boyolali merupakan wilayah yang mengalami perkembangan pesat di Pulau Jawa, Indonesia. Kabupaten Boyolali terdiri dari 75 wilayah perkotaan dan 192 wilayah perdesaan. Kabupaten Boyolali juga termasuk dalam program 100 smart city di Indonesia [1]. Berbagai aspek dinilai menjadi fokus transformasi menuju smart city seperti kemacetan lalu lintas, konsumsi energi, pengelolaan sampah, smart parking, smart lighting, dan masih banyak lagi [2]. Pengelolaan sampah yang belum optimal merupakan salah satu permasalahan di Kabupaten Boyolali $[3,4]$.

Pengolahan sampah di Kabupaten Boyolali masih terbatas di perkotaan, sedangkan di pedesaan masih menggunakan cara tradisional dengan membuang sampah di pekarangan [1]. Komposisi sampah di Kabupaten Boyolali terdiri dari sampah organik, sampah plastik, kertas, logam, kain, kayu, kaca dan B3 (Bahan Berbahaya Beracun). Untuk prosentase masing-masing jenis komponen sampah yaitu untuk sampah plastik memiliki persentase tertinggi sebesar
$56,12 \%$ kemudian terbanyak kedua adalah sampah kebun sebanyak $37,13 \%, 0,35 \%$ berupa sampah makanan, $1,15 \%$ sampah kertas, dan $5,25 \%$ sampah lainnya [5]. Penurunan jumlah sampah plastik dan sampah kebun dapat dilakukan dengan pengolahan. Beberapa penelitian menyebutkan pengolahan sampah plastik dan sampah kebut dapat dilakukan dengan proses karbonisasi $[6,7]$.

Karbonisasi adalah proses konversi termal bahan organik menjadi karbon. Produk arang dapat diproduksi pada suhu dan waktu reaksi karbonisasi tertentu. Suhu dikaitkan dengan jumlah energi yang dibutuhkan untuk memutuskan ikatan kimia bahan baku. Dengan demikian, suhu karbonisasi mempengaruhi jumlah volatil yang dilepaskan dari bahan yang dikarbonisasi, yang kemudian berpengaruh pada hasil arang [8]. Tujuan studi ini adalah untuk melakukan perencanaan pengolahan sampah di Kabupaten Boyolali dengan proses karbonisasi. 


\section{Metode Penelitian}

\subsection{Studi Pendahuluan}

Studi pendahuluan dilakukan untuk mengetahui timbulan dan komposisi sampah di Kabupaten Boyolali. Timbulan dan komposisi sampah didapatkan dari data instansi pemerintah. Studi pendahuuan juga dilakukan untuk mendapatkan literatur yang sesuai untuk dijadikan acuan dalam perencanaan pengolahan sampah di Kabupaten Boyolali.

\subsection{Survei Lokasi}

Survei lokasi dilakukan untuk mengetahu lokasi yang dibuat untuk area pengolahan sampah dengan karbonisasi. Seain itu survey lokasi juga dilakukan untuk mengetahui luas area yang didapat disediakan di Kabupaten Boyolali.

\subsection{Perencanaan}

Perencanaan proses karbonisasi meliputi penentuan jenis sampah yang diolah dan perhitungan material balance. Setelah itu, dilakukan perhitungan kebutuhan proses pengolahan dengan karbonisasi sehingga didapatkan luas lahan yang dibutuhkan. Pembuatan layout dilakukan pada tahap akhir proses perencanaan.

\section{Hasil dan Pembahasan}

\subsection{Perencanaan Awal}

Perencanaan ini menggunakan mesin briket yang akan langsung menghasilkan briket dengan diameter $12 \mathrm{~mm}$. Alat ini memiliki kapasitas sebesar 1 ton/jam. Berdasar data penelitian, 500-gram plastik dan 300gram sampah kebun akan menghasilkan briket sebanyak 558-gram, yang menunjukkan bahwa terdapat penurunan berat sebanyak 8,4\% [9]. Dengan komposisi sampah plastik dan sampah kebun sebesar 90-ton dan 45 ton per hari, akan dihasilkan briket sebesar 92 ton/ hari.

Tabel 1. Nilai kalor sampah plastik dan sampah kebun

\begin{tabular}{ccc}
\hline Jenis Sampah & $\begin{array}{c}\text { Nilai Kalor } \\
\text { (kkcal/kg) }\end{array}$ & Sumber \\
\hline Sampah Plastik & $5183.04-$ & {$[10]$} \\
& 11894.73 & \\
\hline Sampah Kebun & $4018.25-$ & {$[11]$} \\
& 5975.58 & \\
\hline
\end{tabular}

Terdapat beberapa komponen briket yang menentukan kualitas briket. Komponen tersebut meliputi nilai kalor, kadar air, kadar abu, dan kadar volatile matter. Briket dengan kualitas baik adalah briket yang memenuhi nilai standar baku briket. Nilai kalor adalah komponen yang diperlukan sebagai syarat bahan bakar padat pada proses thermal [12, 13]. Menurut Badan Standardisasi Nasional (SNI 16235-2000), nilai kalor minimal dari briket adalah 5000 $\mathrm{kkal} / \mathrm{Kg}$ [13]. Briket sampah plastik dan kebun memiliki nilai kalor sebesar $6121,98 \mathrm{kkal} / \mathrm{Kg}$. Hal ini menandakan bahwa briket sudah memenuhi nilai kalor sesuai standar SNI. Kadar air adalah komponen yang dapat mempengaruhi nilai kalor pada briket. Kadar air yang terlalu tinggi dapat menghambat terjadinya proses pembakaran serta menurunkan nilai suhu gas hasil pembakaran [12]. Hal ini berdampak pada penurunan nilai kalor briket. Berdasar data standar kualitas briket pada SNI 1-6235-2000, briket dengan kualitas baik memiliki kadar air maksimal Terdapat beberapa komponen briket yang menentukan kualitas briket. Komponen tersebut meliputi nilai kalor, kadar air, kadar abu, dan kadar volatile matter. Briket dengan kualitas baik adalah briket yang memenuhi nilai standar baku briket. Nilai kalor adalah komponen yang diperlukan sebagai syarat bahan bakar [12].

Menurut Badan Standardisasi Nasional (SNI 16235-2000), nilai kalor minimal dari briket adalah 5000 $\mathrm{kkal} / \mathrm{Kg}$. Briket sampah plastik dan kebun memiliki nilai kalor sebesar $6121,98 \mathrm{kkal} / \mathrm{Kg}$. Hal ini menandakan bahwa briket sudah memenuhi nilai kalor sesuai standar SNI. Kadar air adalah komponen yang dapat mempengaruhi nilai kalor pada briket. Kadar air yang terlalu tinggi dapat menghambat terjadinya proses pembakaran serta menurunkan nilai suhu gas hasil pembakaran [12]. Hal ini berdampak pada penurunan nilai kalor briket. Berdasar data standar kualitas briket pada SNI 1-6235-2000, briket dengan kualitas baik memiliki kadar air maksimal.

Tabel 2. Nilai Komponen Briket

\begin{tabular}{cc}
\hline Komponen Briket & $\begin{array}{c}\text { Standar Baku Mutu } \\
{[14]}\end{array}$ \\
\hline Nilai Kalor & $>5000 \mathrm{kkal} / \mathrm{kg}$ \\
\hline Kadar Air & $<8 \%$ \\
\hline Kadar Abu & $<8 \%$ \\
\hline Volatile Matter & $<15 \%$ \\
\hline
\end{tabular}

\subsection{Proses Pengolahan}

Pada proses pengolahan sampah menjadi briket, terdapat beberapa tahapan yang dilakukan sebelum akhirnya dihasilkan briket. Sampah plastik dan sampah kebun yang tersedia ditampung dalam bak sampah plastik dan bak sampah kebun. Proses loading sampah ke dalam bak sampah memerlukan dua orang pekerja. Bak sampah plastik dan bak sampah kebun masing-masing dapat menampung sebesar $65.218 \mathrm{~m}^{3}$ dan $93,75 \mathrm{~m}^{3}$ sampah. Proses loading sampah ke dalam mesin karbonisasi dilakukan menggunakan konveyor. Sampah yang berada pada konveyor ditimbang sesuai dengan perbandingan kemudian dimasukkan ke dalam rangkaian mesin karbonisasi. Dalam proses penimbangan sampah serta loading sampah ke dalam rangkaian mesin karbonisasi, diperlukan pekerja sebanyak empat orang pekerja.

Rangkaian mesin karbonisasi terdiri dari beberapa fasilitas pengolahan sampah. Hammer mill adalah alat yang digunakan untuk mencacah sampah yang masuk menjadi potongan yang lebih kecil. Hammer mill dapat menghasilkan partikel sampah dengan diameter 3-5 $\mathrm{mm}$ [15].

Sampah yang telah dicacah kemudian dimasukkan ke dalam rotary drum. Pada rotary drum, partikel sampah dikeringkan pada suhu tinggi. Hal ini bertujuan untuk menghilangkan kadar air pada partikel sampah dan meningkatkan kadar karbon pada partikel sampah sehingga didapatkan produk berupa arang. Arang yang dihasilkan dari tahap ini memiliki temperatur tinggi. Proses pemanasan partikel sampah dilakukan menggunakan autoignition electrix box dengan bahan bakar berupa LPG dan natural gas. 


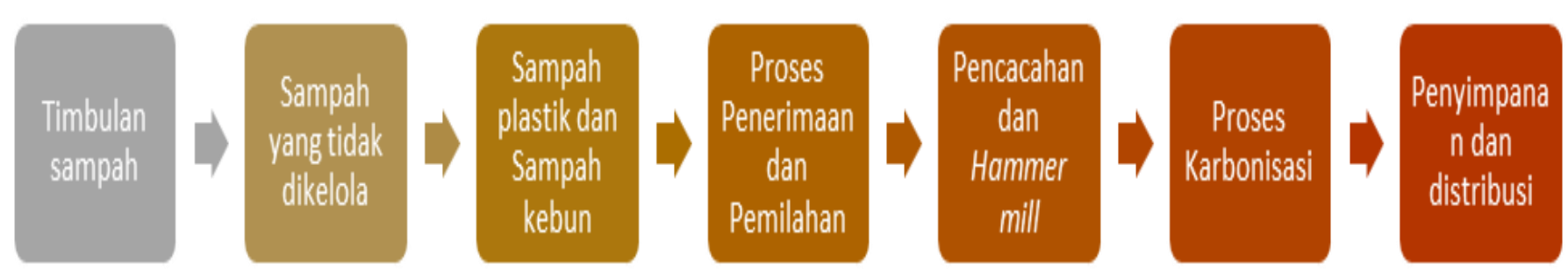

Gambar 1. Perencanaan diagram alir proses pengolahan limbah padat dengan proses karbonisasi di Kabupaten Boyolali

Arang yang telah terbentuk dari proses karbonisasi kemudian didinginkan dan terus diaduk melalui metode water cooling. Pada tahap ini terbentuk partikel arang yang sudah dingin. Arang yang telah dingin kemudian dimasukkan ke dalam mesin pencetak briket sehingga dihasilkan briket yang siap untuk dipakai. Briket yang telah terbentuk kemudian ditampung di dalam bak penampung briket. Bak penampung briket memiliki kapasitas sebesar 10.800 $\mathrm{m}^{3}$. Briket yang tertampung di dalam bak penampung briket kemudian disimpan ke tempat penyimpanan briket. Tahap ini dilakukan menggunakan konveyor. Proses pengangkutan briket ke tempat penyimpanan briket memerlukan pekerja sebanyak tiga orang pekerja. Secara singkat perencanaan diagram proses pengolahan sampah dengan proses karbonisasi dapat dilihat pada Gambar 1.

\subsection{Material Balance}

Dalam perhitungan perencanaan melputi perhitungan total sampah yang akan diolah setiap harinya, ukuran bak penampung sampah sebelum diolah, dan tempat penyimpanan briket hasil pengolahan. Direncanakan proses karbonisasi di Kabupaten Boyolali menggunakan sampah dengan perbandingan sampah plastik dan sampah kebun sebesar 2:1. Perbandingan ini diambil dari kajian literatur dimana menyebutkan perbandingan ini cocok untuk meningkatkan nilai kalor pencampuran antara plastic dan biomassa [16]. Dalam satu hari, alat karbonisasi akan mengolah sampah plastik sebesar 15-ton dan sampah kebun sebesar 7,5-ton dengan menggunakan 6 buah mesin.

Sampah plastik terolah $=$ Komposisi sampah plastik $\times$ Jumlah mesin $=15$ ton $/$ har $i \times 6=90$ ton/hari

Sampah Kebun $=$ Komposisi sampah kebun $\times$ Jumlah mesin $=7,5$ ton $/$ hari $\times 6=45$ ton $/$ hari

Sampah terolah $=($ Komposisi plastik + Komposisi kebun $) \times$ Jumlah mesin $=(15$ ton/hari $+7,5$ ton $/$ hari $)$ $\times 6=135$ ton/hari

Total reduksi sampah dari proses pengolahan sampah dengan karbonisasi adalah 135 ton/hari atau 50,77\% dari total timbulan sampah di Kabupaten Boyolali yaitu sebesar 265.90 ton/hari [5] Berdasarkan Gambar 2 maka dapat dihitung potensi pumulihan energi dari masing-masing sampah yang diolah dengan mengalikan jumlah sampah terolah dan nilai kalor [17] untuk masing-masing jenis sampah plastik dan sampah kebun. Total pemulihan energi dari sampah plastik dan sampah kebun di Kabupaten Boyolali dapat mencapai 5611384,6 MJ/hari.

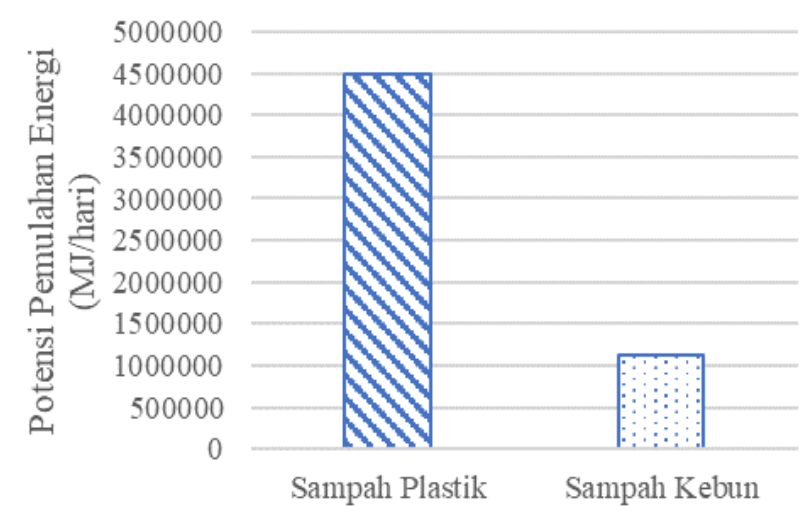

Gambar 2. Potensi Total Pemulihan Energi Sampah Plastik dan Kebun di Kabupaten Boyolali

\subsection{Kebutuhan Lahan}

Perhitungan bak penampung diperlukan untuk mengukur kebutuhan volume bak yang dapat menampung sampah plastik dan sampah kebun yang akan diolah dengan mesin karbonisasi. Dalam perhitugan bak penampungan, terdapat faktor kompaksi untuk mengurangi volume bak penampungan yang sebenarnya. Dengan adanya kompaksi, maka volume bak penyimpanan akan dapat dikurangi. Faktor kompaksi, yang digunakan sebesar 1,5. Berikut merupakan perhitungan volume bak penampungan sampah plastik dan sampah kebun. Menghitung Volume Sampah Plastik yang akan dikelola

\section{Volume Sampah Plastik}

= Massa Sampah Plastik/(Massa Jenis Sampah Plastik $\times$ Faktor Kompaksi)

Volume Sampah Plastik $=90000 \mathrm{~kg} / 0,92 \mathrm{~kg} / \mathrm{m}^{3} \times 1,5$ Volume Sampah Plastik $=65217,4 \mathrm{~m}^{3}$

Volume Sampah Kayu

= Massa Sampah Kayu /(Massa Jenis Sampah Plastik

$\times$ Faktor Kompaksi)

Volume Sampah Kayu $=45000 \mathrm{~kg} / 320 \mathrm{~kg} / \mathrm{m}^{3} \times 1,5$

Volume Sampah Kayu $=93,75 \mathrm{~m}^{3}$ 

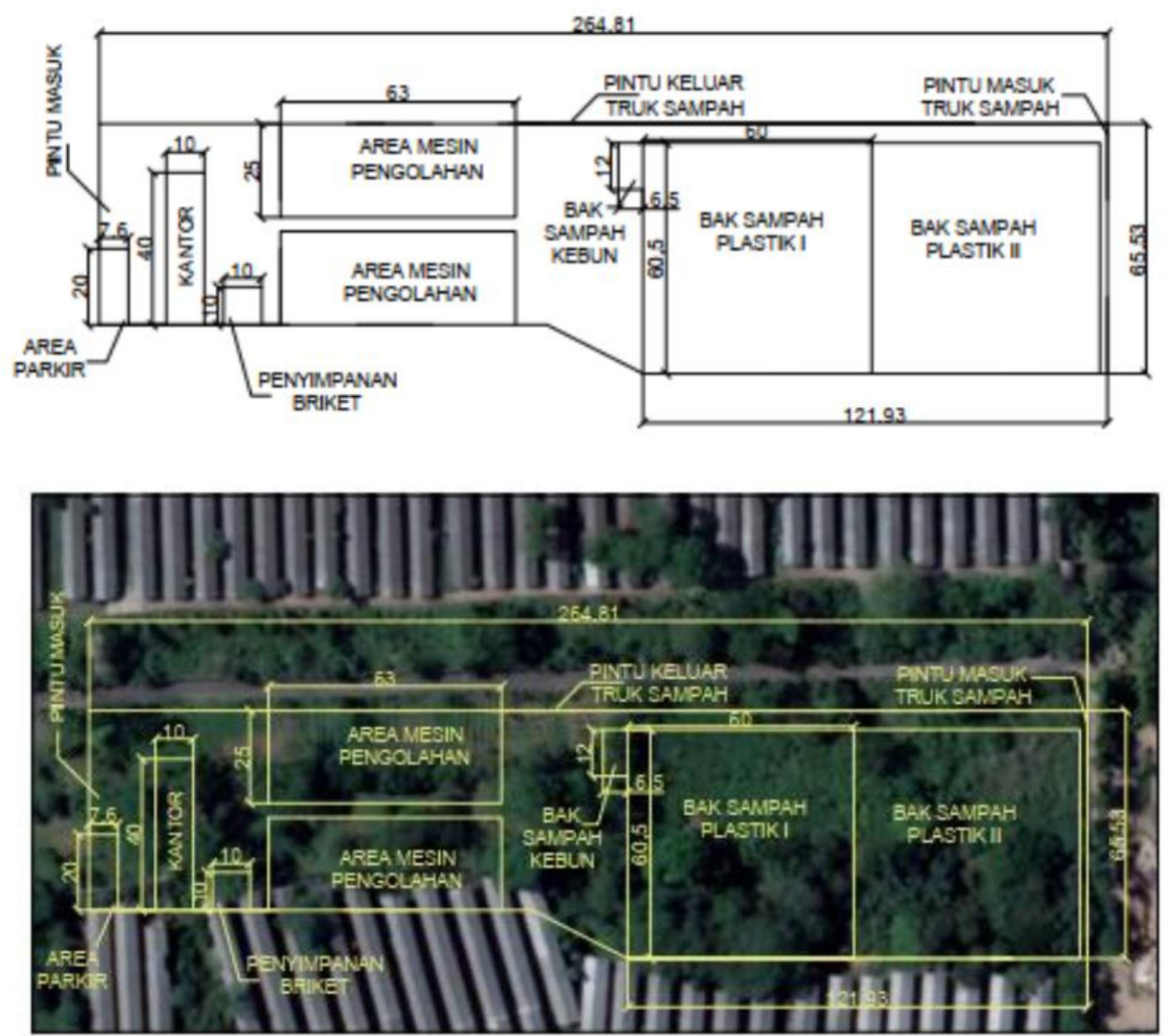

Gambar 3. Layout Perencanaan Proses Pengolahan Karbonisasi di Kabupaten Boyolali

Bak penampungan sampah plastik direncanakan memiliki 1-unit bak. Bak memiliki panjang 120-meter dan lebar 60-meter serta tinggi 1,5 meter. Dari data perencanaan tersebut, dapat dihitung luas lahan yang diperlukan untuk bak penampungan sampah plastik.

Kebutuhan Lahan $=($ Panjang $\times$ Lebar $\times$ Jumlah Bak $)$ $=(120 \mathrm{~m} \times 60 \mathrm{~m} \times 1)=7200 \mathrm{~m}^{2}$

Perencanaan tersebut, dapat dihitung luas lahan yang diperlukan untuk bak penampungan sampah kebun.

Kebutuhan Lahan $=($ Panjang $\times$ Lebar $\times$ Jumlah Bak $)$ $=(12 \mathrm{~m} \times 6,5 \mathrm{~m} \times 1)=117 \mathrm{~m}^{2}$

Bak penyimpanan briket direncanakan memiliki 1-unit bak. Bak memiliki panjang $20 \mathrm{~m}$ dan lebar 10 -meter serta tinggi 1,5 meter. Dari data perencanaan tersebut, dapat dihitung luas lahan yang diperlukan untuk bak penyimpanan briket.

Lahan Penyimpanan Briket $=$ Panjang $\times$ Lebar $=20$ $m \times 10 m=200 m^{2}$.

\subsection{Layout Proses Pengolahan Sampah}

Gambar 3 menunjukkan gambar layout perancangan alat karbonisasi. Gambar tersebut menampilkan informasi mengenai tata letak fasilitas metode karbonisasi serta luas wilayah tiap fasilitas

\section{Simpulan}

Proses karbonisasi di Kabupaten Boyolali direncakan terdiri dari pencacahan, kemudian dilakukan karbonisasi, dan pengemasan briket. Aplikasi pengolahan ini setidaknya dapat mereduksi sampah sebesar $50,77 \%$ dari total timbulan sampah di Kabupaten Boyolali yang tidak tertangani. Proses pengolahan dengan karbonisasi ini membutuhkan luas lahan sebesar $117 \mathrm{~m}^{2}$.

\section{Daftar Pustaka}

[1] Seruyaningtyas, K. (2019, March). Preliminary Study of Smart Regional Waste Recycling in Boyolali, Central Java, Indonesia. In IOP Conference Series: Earth and Environmental Science (Vol. 248, No. 1, p. 012051). IOP Publishing.

[2] Zanella, A., Bui, N., Castellani, A., Vangelista, L., \& Zorzi, M. (2014). Internet of things for smart cities. IEEE Internet of Things journal, 1(1), 22-32. 
[3] Winarto, W., Mahfiana, L., Rosyidah, Z. N., \& Wicaksono, A. (2019). Pendampingan Manajemen Pengelolaan Sampah di Masyarakat Desa Gagaksipat Kecamatan Ngemplak Kabupaten Boyolali. Dimas: Jurnal Pemikiran Agama untuk Pemberdayaan, 19(2), 191-204.

[4] Puspitasari, L., \& Warsono, H. (2019). Analisis Penanganan Sampah Berbasis Masyarakat Di Desa Doplang, Kecamatan Teras, Kabupaten Boyolali. Journal of Public Policy and Management Review, 9(1), 107-119.

[5] Kementerian Lingkungan Hidup. "Sistem informasi Pengelolaan Sampah Nasional 2019". http://sipsn.menlhk.go.id2019.

[6] Grycová, B., Pryszcz, A., Lestinsky, P., \& Chamrádová, K. (2018). Influence of potassium hydroxide and method of carbonization treatment in garden and corn waste microwave pyrolysis. Biomass and Bioenergy, 118, 40-45.

[7] Chen, S., Liu, Z., Jiang, S., \& Hou, H. (2020). Carbonization: a feasible route for reutilization of plastic wastes. Science of the Total Environment, 710, 136250.

[8] Haridan, N. A., Yoshida, H., Salleh, M. A. M., \& Izhar, S. (2020, December). Carbonization of excess sewage sludge using superheated water vapor to produce fuel. In IOP Conference Series: Materials Science and Engineering (Vol. 991, No. 1, p. 012068). IOP Publishing.

[9] Sawir, H. (2016). Pemanfaatan sampah plastik menjadi briket sebagai bahan bakar alternatif dalam kiln di pabrik PT Semen Padang. Jurnal Sains dan Teknologi: Jurnal Keilmuan dan Aplikasi Teknologi Industri, 16(1), 62-69.

[10] Suryawan, I. W. K., Sarwono, A., Septiariva, I. Y., \& Lee, C. H. (2021). Evaluating Marine Debris Trends and the Potential of Incineration in the Context of the COVID-19 Pandemic in Southern Bali, Indonesia. Jurnal IImiah Perikanan dan Kelautan, 13(2).

[11] Ndraha, N. (2009). Uji komposisi bahan pembuat briket bioarang tempurung kelapa dan serbuk kayu terhadap mutu yang dihasilkan. Medan: Universitas Sumatera Utara.

[12] Hastiawan, I. (2018). Pembuatan Briket Dari Limbah Bambu Dengan Memakai Adhesive Pet Plastik $\mathrm{Di}$ Desa Cilayung, Jatinangor. Dharmakarya, 7(3), 154-156.

[13] Qonitan, F. D., Suryawan, I. W. K., \& Rahman, A. (2021, April). Overview of Municipal Solid Waste Generation and Energy Utilization Potential in Major Cities of Indonesia. In Journal of Physics: Conference Series (Vol. 1858, No. 1, p. 012064). IOP Publishing.

[14] Standardisasi Nasional SNI 1-6235-2000

[15] Sarwono, A. Septiariva, I. Y., Qonitan, F. D. Zahra, N. B., Fauziah, E. Ummatin, K. K., Amoa, Q., Faria, N., Lim, J. W., Suryawan, I. (2021). Municipal Solid Waste Treatment for Energy Recovery Through Thermal Waste-To-Energy in Depok City, Indonesia. Journal Of Advanced Research in Fluid Mechanics and Thermal Sciences
[16] Nidhi, C., Sharma, B., \& Singh, P. K. (2017). Energy Value In Biomass And Plastic Components Of Municipal Solid Waste. MATTER: International Journal of Science and Technology, $3(2)$.

[17] Tchobanoglous, G., Theisen, H. dan Vigil, S, A. (1993). Integrated Solid Waste. Management Engineering Principles and Management Issues. Mc Graw Hill. New York. 